\title{
Prison healthcare services: the need for political courage
}

Mary Piper, Andrew Forrester and Jenny Shaw

\section{Summary}

Prisons in England and Wales have reached a low point in service delivery. Despite initial improvements after National Health Service transfer in 2006, it has deteriorated since 2010, with numerous reports giving cause for concern. Improvements are now urgently required, and political courage and a revised national programme of expenditure are necessary.
Declaration of interest

None.

Keywords

Prison; human rights; forensic mental health services.

\section{Copyright and usage}

(c) The Royal College of Psychiatrists 2019
Mary Piper (pictured) is a retired Consultant Geriatrician and Public Health Physician for people in prison in England and Wales. She is an honorary Senior Lecturer in the Offender Health Research Network at the University of Manchester. Andrew Forrester is a Consultant in Forensic Psychiatry with Greater Manchester Mental Health NHS Foundation Trust and an honorary Senior Lecturer at the University of Manchester. His clinical and research interests include mental health in the criminal justice system and other places of detention. Jenny Shaw is Professor of Forensic Psychiatry at the University of Manchester and an honorary Consultant Forensic Psychiatrist with Greater Manchester Mental Health NHS Foundation Trust. Her research interests include suicide, homicide and prison health services research.

The World Psychiatric Association's recent prison public health and educational curriculum statements advocate that internationally, people in prison should have timely access to the same range, volume and standard of mental healthcare that is available in the wider community. ${ }^{1,2}$ The statements are based on the United Nations Standard Minimum Rules for the Treatment of Prisoners, which highlight a respect for the inherent dignity and value of people, with freedom from torture and cruel, inhuman or degrading treatment. ${ }^{3}$ It expects that all governments are clear about the purpose of their prisons, ensuring that imprisonment is reasonable, proportionate, decent and humane, and that the health of detained individuals should not deteriorate as a consequence of the custodial environment or its regimen.

\section{Prison population and spend}

In 2016 the daily prison population of England and Wales was 85348 , a rise of $30 \%$ since $2000 .{ }^{4}$ Approximately 160000 people are detained annually, ${ }^{5}$ of which $24.4 \%$ are held in crowded conditions. ${ }^{6}$ The prison population is becoming notably older: between 2002 and 2016, the number of prisoners aged $>50$ years almost trebled, with 12600 prisoners aged $>50$ years in 2016 - around a seventh of the prison population. ${ }^{6}$

In 2009-2010, day-to-day spending on prisons totalled $£ 3.48$ billion, and in the years that followed this fell by $22 \%$ to $£ 2.71$ billion in 2016-2017. ${ }^{7}$ In the 2018-2019 financial year, further cuts of $£ 400$ million are proposed, with further reductions of $£ 200$ million planned for 2019-2020, ${ }^{8}$ meaning that much more will have to be done with much less. Between 2010 and 2014, sharp cuts to the national prison budget were reflected in falling staff numbers, with the number of core prison staff in public-sector prisons falling by $27 \%{ }^{7}$ Recent government plans to recruit 2500 extra officers ${ }^{7}$ are positive but this recruitment comprises largely inexperienced people, whereas those lost include a significant proportion of officers with $\geq 10$ years' experience. ${ }^{7}$

\section{Recent concerns}

There have recently been a series of unsatisfactory reports of inspections of prison conditions and health services. ${ }^{8}$ Most recently, Her Majesty's Chief Inspector of Prisons found many cells at Exeter prison, built in 1850, to be in a very poor state of repair, with broken windows and leaking lavatories and sinks. ${ }^{9}$ Custodial settings are not health settings; prisoners are largely reliant on lay-carers (prison officers) to act as healthcare gate-keepers. As a consequence, front-line prison operational staff have to be able to recognise a wide range of illnesses before seeking the involvement of healthcare staff.

Data on deaths in custody for the year ending December 2017 showed that 70 prisoners died as a result of suicide, whereas 184 additional deaths were classified as natural; ${ }^{9}$ of these, $30 \%$ were in those aged $<60$ years. Previous studies showed that the most common causes of death were diseases of the circulatory system (43\%), followed by cancer (32\%). ${ }^{10}$ There were three common themes associated with these deaths: referral delays to healthcare staff and outside specialists; delays in response to rapid deterioration in health and summoning emergency services; and poor monitoring of risk factors for significant disease and chronic conditions such as coronary heart disease, asthma, diabetes and epilepsy. ${ }^{10}$

\section{Health-promoting prisons, a diminishing opportunity}

All prisoners became National Health Service patients for the first time in 2006, when commissioning arrangements were fully transferred from Her Majesty's Prison Service. A period of significant investment followed, including the implementation of comprehensive evidence-based substance misuse services in all adult prisons, with increased funding for mental health services. Suicide among substance-misusing prisoners fell immediately, ${ }^{10}$ and following implementation of a prison universal hepatitis B vaccination programme, prisons were the most common source of vaccine among substance misusers. ${ }^{11}$ For a short time, it seemed as if it might really be possible to realise the aspirational 'health-promoting prison' endorsed by the World Health Organisation. ${ }^{12}$

However, this progress was not sustained. By 2016, self-inflicted deaths had risen by $100 \%$ from 2010 . Over that same period, there was a $65 \%$ increase in all natural deaths and a $135 \%$ increase in 
natural deaths of those aged $\geq 60$ years. ${ }^{9}$ Self-harm reached a record high of 42837 incidents in the 12 months to September 2017, up $12 \%$ from 2016, and incidents requiring hospital attendance rose by $15 \%$ to 3007 . The majority of male prisoners making a nearfatal suicide attempt reported they intended to die (73\%), although many acts were found to be impulsive (40\%); half believed their acts could have been prevented, often with relatively simple solutions. All were described as depressed but only $20 \%$ were receiving treatment with antidepressant medication. ${ }^{13}$ Assaults reached a record high of 28165 in 2017, up 12\% from 2016; of these, 3726 (13\%) were serious assaults, up $10 \%$ from $2016 .^{9}$

The Chief Inspectorate's Annual Report for 2016-2017 commented that many prisons struggle to recruit sufficient clinical staff of the right calibre to deliver a safe and effective health service. ${ }^{4}$ Staffing levels in many prisons are simply too low to keep order and run a decent regimen. This leads to reduced time out of cell for prisoners to undertake training and education, or to have access to basic facilities to meet their needs. ${ }^{4}$ Far too many prisoners are being held in conditions that cannot be described as decent. In the vast majority of cases, this is not because of poor staff attitudes or weak leadership. ${ }^{4}$ Prisoners often speak of the need for more meaningful activities such as work, exercise and education, or an increase in contact with family members. ${ }^{14}$ At the same time, however, $74 \%$ say that they are treated with respect, which, in light of the adverse conditions in many establishments, speaks well of the dedication and professionalism of most staff. ${ }^{4}$

\section{Improvement is needed, and political will is essential}

In 1910, Home Secretary Churchill said that 'the mood and temper of the public regarding treatment of crime and criminals is one of the most unfailing tests of the civilisation of any country. ${ }^{15}$ What does this say for our society today?

Prisoners present with inordinate levels of social disadvantage and evidence of marginalisation: $48 \%$ were unemployed before custody, $47 \%$ have no qualifications, $42 \%$ were expelled from school, $15 \%$ were homeless before imprisonment and $13 \%$ have never had a job. Further, $54 \%$ have children aged $<18$ years, and $19 \%$ of those aged 18-20 years are young fathers.

Prison should provide an opportunity to engage with this hard-toreach group to address their health and social care needs. Around one in seven prisoners have a treatable mental illness: $4 \%$ have psychosis, $10-12 \%$ have major depression and $40-70 \%$ have a personality disorder. ${ }^{16}$ Further, $10-48 \%$ of men and $30-60 \%$ of women misused or were dependent on illegal drugs at prison reception. ${ }^{14}$ Three-quarters of prisoners who were homeless before custody were reconvicted in the first year after release ${ }^{17}$ Knowing these facts yet failing to act represents a form of State-level neglect, particularly when we know that more can be done when we bring adequate resources to bear.

\section{The way forward}

Prison medicine is one of the most exciting branches of medicine, with complex, challenging and rewarding patients. Within austerity-level resource allocation and working conditions, however, professionals are unable to provide the quality of healthcare delivery that prisoners' multiple needs require.

Instead of seeking to reduce the national spend on prisons even further, the government must now fully acknowledge the depth and scale of the problems prisons face. Significant financial resources should be allocated as a matter of priority, to restore decent, safe and humane conditions across the board, with access to effective healthcare and rehabilitation. Prisoners and prison operational and healthcare staff deserve exactly that, and nothing less. Prison staff must undertake their important and vital work safely, allowing them to be proud and fulfilled in all that they do, rather than living in dread of the next catastrophic event and potential public rebuke.

Prisoners require the necessary range and volume of health services to deliver health promotion, prevention and treatment of health disorders so that on release they are healthier and can lead productive lives. Staff should be well trained and prisons should be accessible to multidisciplinary trainees, including medical students, with the promotion of effective continuing professional development of trained prison mental health staff. ${ }^{2}$

Reducing the prison population is an imperative. The imaginative implementation of community alternatives to imprisonment should now proceed alongside consideration of the release of those imprisoned for public protection (indeterminate sentences for public protection, or IPPS; a sentence abolished in 2012).

Substantial national improvements are within our grasp, but require societal will, political courage and a revised programme of expenditure. If not, we will continue to fall short of Churchill's classification of a civilised society and people in prison will be failed in detention, and after release to the community.

Mary Piper, Consultant in Forensic Psychiatry, Greater Manchester Mental Health NHS Foundation Trust; and Honorary Senior Lecturer in Forensic Psychiatry, University of Manchester, UK; Andrew Forrester, Consultant in Forensic Psychiatry, Mersey Care NHS Foundation Trust; and Honorary Senior Lecturer in Forensic Psychiatry, University of Manchester, UK; Jenny Shaw, Professor of Forensic Psychiatry, University of Manchester; and Honorary Consultant Psychiatrist, Greater Manchester Mental Health, UK

Correspondence: Andrew Forrester, Edenfield Centre, Bury New Road, Prestwich, Manchester M25 3BL, UK. Email: andrew.forrester1@nhs.net

First received 9 Aug 2018, accepted 19 Nov 2018

\section{References}

1 Forrester A, Piper M, Chadda R, Exworthy T, Farrell M, Fazel S, et al. World Psychiatric Association Prison Public Health Position Statement. World Psychiatric Association, 2017 (http://wpanet.org/uploads/Position_Statement/ WPA\%20Position\%20Statement\%20prison\%20policy\%20fin.pdf).

2 Forrester $\mathrm{A}$, Piper $\mathrm{M}$, Chadda R, Exworthy $\mathrm{T}$, Farrell $\mathrm{M}$, Fazel $\mathrm{S}$, et al. World Psychiatric Association Prison Public Health Position Statement. World Psychiatric Association, 2017 (http://wpanet.org/uploads/Position_Statement/ WPA\%20Prisoner\%20Mental\%20Health\%20care\%20curriculum\%20fin.pdf).

3 United Nations General Assembly. The UN Standard Minimum Rules for the Treatment of Prisoners (the Nelson Mandela Rules). United Nations General Assembly, 2015 (http://www.un.org/en/events/mandeladay/mandela_rules. shtml).

4 Allen G, Watson C. UK Prison Population Statistics, Briefing Paper SN/SG/ 04334. House of Commons Library, 2017 (https://researchbriefings.parliament.uk/ResearchBriefing/Summary/CBP-7892).

5 Prison Reform Trust. Bromley Briefings Prison Factfile. Prison Reform Trust, 2017 (http://www.prisonreformtrust.org.uk/Portals/0/Documents/Bromley\% 20Briefings/Autumn\%202017\%20factfile.pdf).

6 Her Majesty's Inspectorate of Prisons for England and Wales (HMIP). Annual Report 2016-17. HMIP, 2017 (https://www.justiceinspectorates.gov.uk/hmiprisons/inspections/annual-report-2016-17/).

7 Institute for Government. Prisons. Institute for Government, 2018 (https:// www.instituteforgovernment.org.uk/publication/performance-trackerautumn-2017/law-and-order/prisons)

8 Her Majesty's Inspectorate of Prisons for England and Wales (HMIP). Report on an Unannounced Inspection of HMP Liverpool. HMIP, 2017 (https://www.justiceinspectorates.gov.uk/hmiprisons/wp-content/uploads/sites/4/2018/01/ HMP-Liverpool-Web-2017.pdf)

9 Her Majesty's Chief Inspector of Prisons. Urgent Notification: HM Prison Exeter. HM Inspectorate of Prisons for England and Wales, 2018 (https://www. justiceinspectorates.gov.uk/hmiprisons/wp-content/uploads/sites/4/2018/ 05/Exeter-UN-letter-and-debrief-for-publication.pdf). 
10 Prisons and Probation Ombudsman (PPO). Learning from PPO Investigations: Natural Cause Deaths in Prison Custody 2007-2010. PPO, 2012 (http://www. ppo.gov.uk/app/uploads/2014/07/learning_from_ppo_investigations-natural_ cause_deaths_in_prison_custody.pdf).

11 Shaw J, Wainwright V, Webb R, Appleby L, Piper M, Rees J, Elder R. National Study of Self-Inflicted Death by Prisoners 2008-2010. University of

Manchester, Ministry of Justice and Department of Health, 2013 (http://

research.bmh.manchester.ac.uk/cmhs/research/centreforsuicideprevention/ suicideinprisons/report_2013.pdf).

12 Hope V, Ncube F, Hickman M, Judd A, Parry JV. Hepatitis B vaccine uptake among injecting drug users in England 1998 to 2004: is the prison vaccination programme driving recent improvements? J Viral Hepat 2007; 14: 653-60.
13 Woodall J. Health promoting prisons: an overview and critique of the concept. Prison Serv J 2012; 202: 6-11.

14 Rivlin A, Fazel S, Marzano L, Hawton K. The suicidal process in male prisoners making near-lethal suicide attempts. Psychol Crime Law 2011; 4: 305-27.

15 House of Commons Speech [1910] July 20th per Churchill W.

16 Independent Advisory Panel on Deaths in Custody. Keeping Safe - Preventing Suicide and Self-Harm in Custody: Prisoners' Views. Independent Advisory Panel on Deaths in Custody, 2017 (http://iapdeathsincustody.independent. gov.uk/wp-content/uploads/2017/12/Keeping-Safe-FINAL-Dec-2017.pdf).

17 Fazel S, Baillargeon J. The health of prisoners. Lancet 2011; 377 (9769): 956-65. 